DOI: $10.14451 / 2.159 .7$

\title{
АДМИНИСТРАТИВНО-ПРАВОВОЕ РЕГУЛИРОВАНИЕ СОЛИДАРНОЙ ЭКОНОМИЧЕСКОЙ ДЕЯТЕЛЬНОСТИ ГОСУДАРСТВА И ТЕХНОЛОГИЧЕСКОГО ПРЕДПРИНИМАТЕЛЬСТВА
}

\author{
(c) 2021 Щукина Татьяна Владимировна \\ доктор юридических наук, доцент \\ ведущий научный сотрудник сектора административного права и процесса \\ Институт государства и права РАН, Россия, Москва
}

Предметом настоящей статьи выступает исследование новых принципов управленческой деятельности органов публичной власти в экономической деятельности Российской Федерации при реализации стратегических задач развития государства. Тема статьи отражает вопросы роли и содержания управляющего воздействия государства на общественные отношения, интеграции принципов солидарности в современной экономической деятельности государства, включая сферу высокотехнологичного предпринимательства. Целью настоящей статьи являются выявление сущности современного управления в системе исполнительных органов государственной власти, солидарного управления в сфере экономической деятельности, понимания условий модификации форм и методов управленческой практики обеспечения солидарности взаимодействия общества и государства по исполнению национальных целей и задач развития Российской Федерации. Также установление возможностей перехода к солидарному управлению в сложившихся экономических условиях, места и роли государства в этом процессе. Методологию данной работы составили сравнительный, формально-юридический, аналитический методы. Результаты работы - это формулирование роли и содержания новых интеграционных инструментов правового регулирования управленческой деятельности в органах государственной власти в условиях цифровизации и модернизации экономики. Область применения результатов работы включает в себя государственную политику в области стратегического развития и управления.

Ключевые слова: стратегическое развитие Российской Федерации, управление, экономическая и социальная солидарность, солидарная экономика, солидарное управление

Рассмотрение правовых терминов «управление», «государственное управление» и иных понятий, близких по своему значению и смысловому содержанию, осуществлялось учеными на протяжении многих десятилетий. И до сих пор дискуссии по этому поводу не прекращаются, а перманентно возникают и наполняются новыми смыслами, исходя из реалий проводимой государственной политики, сложившихся традиционных форм управленческой деятельности в органах государственной власти, социально-экономических отношений и социальных ценностей, признанных в том или ином обществе или государстве.

Управление как определенное воздействие уполномоченных субъектов на участников общественных отношений, попадающих в орбиту конкретной модели взаимодействия управленческой элиты (персонала государственной службы) и общества, сохраняется и продолжает существовать, периодически трансформируясь. В настоящее время вопрос о месте, роли и содержании управляющего воздействия государства на общественные отношения и соответственно их непосредственных участников как никогда актуален. Серьезные изменения сущности общественных отношений, порядка и условий взаимодействия органов государственной власти и общества; усиленное влияние международных стандартов в этой сфере 
предопределяют новые методы и формы управленческой деятельности.

По мнению автора, факторами происходящих модификаций управленческого воздействия на участников общественных отношений выступают:

a) изменение системы экономической деятельности государства и принципов хозяйствования, социальной защиты населения; взаимоотношений между государственным паттерном и различными секторами общества, включающими неоднородные по своим характеристикам социальные группы, которые при определенных условиях объединяются в сетевые сообщества, влияющие на выстраивание государственных стратегий развития;

б) усложнение задач управленческой деятельности в связи с децентрализацией и деконцентрацией полномочий органов государственной исполнительной власти;

б) внедрение прогрессивных технологий цифровизации в управленческом процессе, да и в целом в общественно-социальном устройстве;

в) неустойчивое состояние жизнеобеспечения общества ввиду неравномерного распределения природных и иных ресурсов, экологического и иного неблагополучия (природные катаклизмы, эпидемии и т.п.).

В подобных условиях развитие государства и общества зависит от того, каким образом политико-властные структуры государства смогут выстроить систему регулирования, планирования, контроля и др. управленческого воздействия на множественность факторов, дестабилизирующих систему управления. Появляется многозадачность компетенции органов государственной власти и многовекторность направлений ее реализации, что требует особого формата властно-управленческого воздействия и ответных форм на него со стороны множества участников общественных отношений. Отметим, что современный ландшафт участников общественных отношений, попадающих под государственное влияние, существенно изменился и пополнился новыми участниками с неоднозначным правовым статусом, компетенцией и полномочиями. Рассмотрение функционирования подобных участников управленческих отношений (государственные корпорации, Пенсионный фонд Российской Федерации, Центральный Банк Российской Федерации, юридических лиц с публичным элементом и др.) с точки зрения устоявшихся в середине XX века представлений ученых юристов о государственном управлении, не представляется возможным. Одновременно нельзя и отрицать позитивное содержание выводов, мнений и научных основ государственного управления, сформулированных в середине XX столетия советскими учеными.

Философия управления современного этапа развития общества требует обновления научного видения терминов, касающихся теории государственного управления, и сущности его правового регулирования. Неизменность терминологического подхода к толкованию понятий, отождествляемых с процессом государственного управления в современном мире, не возможна. Динамичное изменение всех общественно-государственных процессов, включая социальные, политические, экономические, географические и экологические, не позволяет сохранять статику теоретизирования понятийно-категориального аппарата в сфере воздействия органов государственной власти, включая органы исполнительной власти, на участников управленческих отношений и упорядочения их деятельности. Отменить властное управляющее воздействие на участников общественных отношений со стороны государства в полной мере нельзя, поэтому необходимо определить характер подобного воздействия, его виды и установить, что же стоит понимать под управлением, которое реализуется всеми органами публичной власти. В чем оно выражается, чем отличается или является аналогичным для всех видов органов публичной власти. 
Вопросы модификации управления затрагивались неоднократно советскими учеными, они отмечали, что «развитие научно-технического прогресса, усложнение производства и всей общественной жизни, рост народнохозяйственного и социально-культурного строительства приводят к повышению роли управления в социалистическом обществе. Недооценка задачи совершенствования управления, отставание в этой области причиняли и могут причинить в современных условиях большой ущерб развитию экономики, культуры, науки и других сфер общественной жизни» [1]. С их точки зрения, управление необходимо для «повышения эффективности общественного производства, ускорения темпов создания материальнотехнической базы, улучшения руководства социально-культурным строительством, обороной, охраной общественного порядка и безопасности; для оперативного решения возникающих вопросов» [2].

В советский период государственное управление в широком смысле рассматривалось «как управление только государственными делами» [3]. Кроме того, «государственное управление связывалось с категорией властвования; выступало как процесс функционирования власти и означало, прежде всего, выработку и проведение внутренней и внешней политики, экономической политики, регулирование общественных отношений и поведения людей, организацию их совместной деятельности в процессе производства и в различных сферах общественной жизни» [4]. Узкое понятие государственного управления представляло собой «деятельность государственных исполнительно-распорядительных органов» [5]. Обобщающее содержание государственного управления выражалось в следующем: «Управление в советском социалистическом государстве представляет собой организующую работу государственных органов, направленную на объединение усилий граждан, государственных органов, учреждений, предприятий и ор- ганизаций для решения задач экономического, социально-культурного и административнополитического характера» [6]. Заметим, что и в тот период времени, ученые отмечали ведущую роль государства «в творчески-созидательной природе государственного управления» [7], а также «организаторскую деятельность государственных органов, базировавшуюся на праве как важном факторе регулирования общественных отношений» [8].

По сути, государство обязано управлять обществом в целях защиты прав и свобод граждан, обеспечения правопорядка и обороноспособности страны, предотвращения воздействия на нее любых несанкционированных внешних посягательств экономического, военного и иного характера. Государство создает и помогает создавать, охранять социально-культурные ценности, социально-экономическую, инженерную инфраструктуру городов и малых населенных пунктов; обеспечивает достойные условия для жизни, здоровья и экологически комфортного проживания населения и многое другое. Заметим, что Президент Российской Федерации В.В.Путин неоднократно отмечает на проводимых совещаниях необходимость социальной поддержки населения: «на ближайшие три года необходимо сформировать федеральный бюджет как бюджет развития, так как он выступит мощным инструментом для достижения национальных целей в области экономики в целом, инфраструктуры, экологии, социальной сферы, повышения доходов граждан» [9]. Государство заинтересовано в укреплении и развитии культурной, социальной, экономической сферы управления, поэтому государство управляет. Оно оказывает, кроме того, «определенное воздействие на сознание и поведение людей; управляет в целом людьми» [10].

В чем же выражается современное воздействие государства на общество? Это, прежде всего, выработка государственной политики и государственных стратегий развития Российской Федерации. Государственная политика 
зиждется на правовых нормах и отражается в федеральных законах, указах Президента Российской Федерации, постановлениях Правительства Российской Федерации, носящих стратегический характер. Федеральный закон от 25 декабря 2008 г. № 273-ФЗ «О противодействии коррупции» закрепляет проведение единой государственной политики в области противодействия коррупции. В свою очередь, федеральный закон от 24 июля 2007 г. № 209-Ф3 «О развитии малого и среднего предпринимательства в Российской Федерации» регулирует государственную политику в области развития малого и среднего предпринимательства в Российской Федерации как часть государственной социально - экономической политики. Федеральный закон от 28 июня 2014 г. № 172-Ф3 «О стратегическом планировании в Российской Федерации» раскрывает основы по целеполаганию, прогнозированию, планированию и программированию социально-экономического развития Российской Федерации.

Указы Президента Российской Федерации определяют стратегические направления государственной политики во всех сферах и областях государственной и общественной жизни: развития Арктической зоны Российской Федерации, международной информационной безопасности [11], научно-технической политике [12], научно-технической политике в области экологического развития [13], продовольственной безопасности [14], государственной экономической политике [15] и др.

Правительство Российской Федерации осуществляет разработку государственной политики, основывающуюся на федеральных законах и нормативных правовых актах Президента Российской Федерации стратегического характера. В развитие основ стратегического планирования Правительством Российской Федерации были разработаны Правила общественного обсуждения проектов документов стратегического планирования по вопросам, находящимся в ведении Правительства Российской Феде- рации [16], Правила разработки, корректировки, осуществления мониторинга и контроля реализации отраслевых документов стратегического планирования Российской Федерации [17] и другие.

Указы Президента Российской Федерации дополняются Правительством Российской Федерации на основании поручений главы государства [18] соответствующими постановлениями: о социально-экономическом развитии Арктической зоны Российской Федерации [19], о поддержке программ развития образовательных организаций высшего образования в рамках реализации программы стратегического академического лидерства «Приоритет-2030» [20], об инновационной экономике [21], о мерах по обеспечению устойчивого развития [22] экономики. В нормативных правовых актах, касающихся государственной политики и стратегий развития государства, прослеживается тенденция интеграции и кооперации деятельности главы государства и всей системы федеральных органов исполнительной власти, включая Правительство Российской Федерации. Согласно стратегическим правовым актам исполнительная власть действует в своем единстве согласно стратегическим целям и задачам, определяемым Президентом Российской Федерации [23].

Это современное проявление политической солидарности, которая отражается в координационных стратегиях [24] и иных государств. Аналогичный формат прослеживался также в советское время, где «идею единства всех органов государства, выполняющих единые задачи в рамках своей компетенции методами, присущими каждому государственному органу, предусматривало управление. Не смотря на разграничение компетенции между органами и использование каждым из них специфических методов деятельности, это не ослабляло их единства в осуществлении функций государства, в проведении мер, обеспечивающих строительство общества» [25]. Единство воздействия органов государственной исполнитель- 
ной власти, Президента Российской Федерации и Правительства Российской Федерации на общественные отношения в рамках стратегического планирования, решения национальных целей и задач развития государства - является неоспоримым фактом в настоящее время.

Сущность воздействия варьируется от прямого властного воздействия (управления) до форм регулирования, координации и кооперации. Кооперация и координация как управляющее воздействие органов государственной исполнительной власти отличается от содержания ранее существовавших функций регулирования и координации. Это выражается в большей степени привлечения различных секторов общества, уровня свободы их действий в решении общих стратегических задач, стоящих перед Российской Федерацией. Подобная кооперация формируется в ключе разнообразных партнерств: государственно-частное партнерство, социальное партнерство, партнерство в социальных добровольческих проектах, партнерство предприятий в промышленных кластерах, кооперативное движение, партнерство органов государственной власти субъектов Российской Федерации, бизнеса, научных и образовательных организаций для развития отраслей экономики и регионов, субсидирование технологического [26] предпринимательства. Фонд содействия развитию инноваций, Агентство стратегических инициатив, Минобрнауки Российской Федерации систематически проводят крупные форумы, где оказывают консультационную, информационную, партнерскую помощь для технологических стартапов, а также выделяют гранты на создание высокотехнологичных предприятий (акселератор Архипелага 2121, обучение в предакселераторе, венчурное финансирование). Управляющее воздействие государства на общественные сектора в форме кооперации и применения косвенных методов управления стало всеобъемлющим явлением и неотъемлемым элементом государственного воздействия.
Прямое регулирующее и управляющее воздействие государства в системе публичного управления все больше становится косвенным и координирующим с элементами кооперации, но в любом случае оно остается управляющим. Управляющим властным действием с разными формами и уровнями регулирования и воздействия на общественные отношения. К этому прибавляется еще и демократизация подобного воздействия, основывающаяся на принципах политической, экономической и социальной солидарности. Конституционный принцип солидарности и обновленные формы взаимодействия государства и общества в рамках президентского утверждения стратегических целей и задач развития России порождают солидарное управление. По мнению автора, «формы экономической, политической и социальной солидарности выстраиваются в реальном измерении на первоначальной инициативе государства, его правовом регулировании и стратегических правовых документах. Наряду с традиционными формами солидарности возникают новые формы, которые соответствуют запросам общества и социально-экономической ситуации. Координация и кооперация государства и общества по общим значимым целям и задачам, отвечающая общим интересам, превращающаяся в прогрессивную публичную деятельность, урегулированную правовыми нормами и этическими нормами (справедливости и т.п.) и является современной моделью солидарности. Солидарность требует не только переосмысления сущности отношений между субъектами, но и социально-нравственных основ этих отношений. Солидарность невозможно обеспечить исключительно правовыми средствами, это целый комплекс воздействий на общество и государство. Начиная от принципов и стратегии государственной политики, и завершая нравственным осмыслением гражданином своей роли и значения в солидарных отношениях» [27]. 


\section{Библиографический список}

1. Научные основы государственного управления в СССР / под ред. А.Е. Лунева, М.И.Пискотина, Ц.А. Ямпольской. М.: Издательство «Наука», 1968. С. 5.

2. Научные основы государственного управления в СССР. М., 1968. С. 5-8.

3. Научные основы государственного управления в СССР. М., 1968. С. 14.

4. Научные основы государственного управления в СССР. М., 1968. С. 14-15.

5. Научные основы государственного управления в СССР. М., 1968. С. 18.

6. Научные основы государственного управления в СССР. М., 1968. С. 18.

7. Научные основы государственного управления в СССР. М., 1968. С. 19.

8. Научные основы государственного управления в СССР. М., 1968. С. 19.

9. Путин не исключил дополнительных мер поддержки россиян: [Электронный ресурс]. Режим доступа: https://news.mail.ru/society/48123888/?frommail=1\& exp_id=942

10. Розенбаум Ю.А. Формирование управленческих кадров: социально-правовые проблемы. М.: Издательство «Наука», 1982. С. 15.

11. Об утверждении Основ государственной политики Российской Федерации в области международной информационной безопасности: Указ Президента РФ от 12 апреля 2021 г. № 213 // Собр. законодательства Рос. Федерации. 2021. № 16 (часть I). Ст. 2746.

12. О мерах по повышению эффективности государственной научно-технической политики: Указ Президента РФ от 15 марта 2021 г. № 143 // Собр. законодательства Рос. Федерации. 2021. № 12. Ст. 1982.

13. О мерах по реализации государственной научно-технической политики в области экологического развития Российской Федерации и климатических изменений: Указ Президента РФ от 8 февраля 2021 г. № 76 // Собр. законодательства Рос. Федерации. 2021. № 7. Ст. 1098.

14. Об утверждении Доктрины продовольственной безопасности Российской Федерации: Указ Президента РФ от 21 января 2020 г. № 20 // Собр. законодательства Рос. Федерации. 2020. № 4. Ст. 345.

15. О долгосрочной государственной экономической политике: Указ Президента РФ от 7 мая 2012 г. № 596 // Собр. законодательства Рос. Федерации. 2012. № 19. Ст. 2333.

16. Об утверждении Правил общественного обсуждения проектов документов стратегического планирования по вопросам, находящимся в ведении Правительства Российской Федерации, с использованием федеральной информационной системы стратегического планирования: постановление Правительства РФ от 30 декабря 2016 г. № 1559 // Собр. законодательства Рос. Федерации. 2017. № 2 (часть II). Ст. 387.

17. Об утверждении Правил разработки, корректировки, осуществления мониторинга и контроля реализации отраслевых документов стратегического планирования Российской Федерации по вопросам, находящимся в ведении Правительства Российской Федерации: постановление Правительства РФ от 29 октября 2015 г. № 1162 // Собр. законодательства Рос. Федерации. 2015. № 45. Ст. 6253.

18. Поручение Президента РФ от 5 августа 2021 г. № Пр-1383 «Перечень поручений по итогам заседания Совета по стратегическому развитию и национальным проектам».

19. Об утверждении государственной программы Российской Федерации «Социальноэкономическое развитие Арктической зоны Российской Федерации»: постановление Правительства РФ от 30 марта 2021 г. № 484 // Собр. законодательства Рос. Федерации. 2021. № 14. Ст. 2352.

20. О Совете по поддержке программ развития образовательных организаций высшего образования в рамках реализации программы стратегического академического лидерства «Приоритет-2030»: постановление Правительства РФ от 13 мая 2021 г. № 730 // Собр. законодательства Рос. Федерации. 2021. № 22. Ст. 3824.

21. О внесении изменений в государственную программу Российской Федерации «Экономическое развитие и инновационная экономика»: постановление Правительства РФ от 31 марта 2021 г. № 513 // Собр. законодательства Рос. Федерации. 2021. № 16 (часть I). Ст. 2761. 
22. О мерах по обеспечению устойчивого развития экономики: постановление Правительства РФ от 2 апреля 2020 г. № 409 // Собр. законодательства Рос. Федерации. 2020. № 15 (часть IV). Ст. 2267.

23. О национальных целях и стратегических задачах развития Российской Федерации на период до 2024 года: Указ Президента РФ от 7 мая 2018 г. № 204 // Собр. законодательства Рос. Федерации. 2018. № 20. Ст. 2817.

24. Кулакова T.А. Принуждение и солидарность как способы координации в политическом управлении // Известия Российского государственного педагогического университета им. А. И. Герцена. 2011. № 143. С. 167.

25. Научные основы государственного управления в СССР. М., 1968. С. 18.

26. Стратегия академического лидерства «Приоритет 2030».

27. Публичная власть: система, компетенции: монография.-C.204-205 (Щукина T. B. - Раздел III, п. 3.2). 